\title{
An Investigation on Construction Crisis Framework Based on the CRITIC and WASPAS Methods, a Case Study; Khuzestan province (Iran)
}

\author{
Seyed Ali Mousavi Dehmourdi, M. Gopal Naik, Ravande Kishore
}

\begin{abstract}
The crises in construction industry are deemed a negative event in the security, economic, political, materials, or natural affairs, especially when they occur abruptly, with little or no warning; and it has always caused damage, therefore crisis management is necessary to order not turn crisis into a disaster. The present study focuses on exploring the impact of the crisis in construction projects by offering a review of the literature to identify the various associated crisis and made a case study of "Khuzestan province (Iran). First, through a questionnaire survey with construction experts as respondents, the initial list of 222 sub-factors were confined to a list of 174 essential crisis sub factors and were grouped under 20 main crisis factors. Second, the shortlisted 174 essential crisis sub factors conduct a questionnaire-based survey with top experts from "Khuzestan province (Iran) construction organization as respondents to obtain the Importance of each sub factors based on the rating of its impact the second list and using CRITIC method to weighting crisis factors. Third, ranking the influential sub crisis factors from the all sub factor list and provide a single list without considering the initial list crisis through WASPAS model. Finally, The result of the crisis effects rating, seen that the most crisis effects rating in the Khuzestan construction industry is the economic crisis, followed by the market and real estate, and then insurance, maintenance, after that respectively, logistics, and materials crises. Identify the crisis is the main part of crisis management; the obtained results help construction crisis managers and all stakeholders to achieve sustainable development in construction projects. Identifying and prioritizing construction-specific crises allow sustainable crisis managers to concentrate to be successful projects.
\end{abstract}

Keywords: Construction Crisis, CRITIC, WASPAS, MCDM Methods.

Manuscript received on March 26, 2021.

Revised Manuscript received on April 17, 2021.

Manuscript published on April 30, 2021.

* Correspondence Author

Seyed Ali Mousavi Dehmourdi*, Research Scholar, Department of Civil Engineering, University College of Engineering, Osmania University, Hyderabad, India.

M. Gopal Naik, Professor, Department of Civil Engineering, University College of Engineering, Osmania University, Hyderabad, India.

Ravande Kishore, Principal, MIT School of Engineering, Pune, Maharashtra, India.

(c) The Authors. Published by Blue Eyes Intelligence Engineering and Sciences Publication (BEIESP). This is an open access article under the CC BY-NC-ND license (http://creativecommons.org/licenses/by-nc-nd/4.0/)

\section{INTRODUCTION}

$\mathrm{T}$ he construction industry is one of the most thriving and flourishing industries in the whole world and one of the largest industries in Asia, this industry is mainly an urban-based one, which is concerned with preparation as well as construction of real estate properties. The maintenance or reconstruction or any construction need the update techniques and lack of use or unknowing or inaccessible with now technique can irreparable injuries to this largest industry. Construction projects are complex endeavors, associated with large costs and long duration. Iran's construction industry has undergone extensive development in terms of infrastructure due to extensive construction programs. A reason for the crises in the construction projects is their flexibility, unwillingness, and unfollow of formal, standardized systems and procedures which serve them well in normal times but which become restrictive and counter-productive during a crisis, so the crisis is always happening in construction projects and it has always caused damage, and crisis management is necessary to order not to turn crisis into a disaster. The possible for crises through the life of a construction project is massive. This is because of in part, to the progressively technical and organizational complication that is affecting all industries, but also to the construction industry's peculiar culture and decision-making practices. A crisis may be abrupt or cumulative; an abrupt crisis is a sudden impact of internal or external disturbances that is generally more specific but a cumulative crisis can be foreseen although it also breaks suddenly [1]. A crisis can consist of four elements are common to most definitions of crisis ; (i) A threat to the organization (ii) The element of surprise (iii) A short decision time (iv) Where the old system can no longer be maintained [2]. Crises that can affect construction companies occur either periodically or suddenly. Such companies in the pursuit of an innovative crisis management approach should be ready against any types of crises. Because of the fact that construction companies should deal with high investment costs, crises can adversely and significantly influence these companies [3]. Crisis management is a method, technique and an application of strategies designed to help the company member such as staff or managers or supervisors or any other person who has responsibility organization.

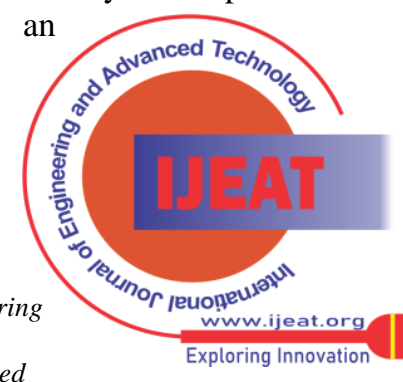


A crisis is any event that is going (or is expected) to lead to an unstable and dangerous situation affecting an individual, group, community, or whole society.

Crises are deemed negative changes in the security, economic, political, societal, or environmental affairs, especially when they occur abruptly, with little or no warning. More loosely, it is a term meaning "a testing time" or an "emergency event .

The crisis in the industry can differ in its timing, and divided into three categorize including creeping crisis, periodic crisis, and sudden crisis [1]. The necessity in the investigation of the construction crisis in "Khuzestan province (Iran) " gets back to the lack of relevant study comprising the various crisis factors to demystify, weigh and rank the criteria in this regard, Also, there isn't a framework for identification systematic and nonsystematic crisis as a causal model for the construction crisis in the projects. Therefore, our effort spent on the identification of all the construction crises extracted from existing literature that categorized in a questionnaire including 20 factors and 174 sub-factors. It was worth mentioning that nobody works out on this field in "Khuzestan province (Iran) ", so this study tried to cover this gap and helps stakeholders to reach sustainable development in construction projects. The following also encompasses the same descriptions. Many previous studies only focused on the economic, natural and environmental crisis but the present study tries to identify and categorize all types of crises in the "Khuzestan province (Iran) " construction industry. Khuzestan province is one of the 31 provinces of Iran; it has located in the southwest of Iran, next to Iraq, and close to the Persian Gulf. Its capital is Ahwaz and covers an area of 63,238 square kilometers. Various researchers have explored crisis in construction and contributed the necessary proof for validating their importance, but from the MCDM, there is no prioritization weights and assessment of the crisis in "Khuzestan province (Iran) "construction projects Therefore, this study contributes to knowledge by providing a deeper understanding of how MCDM works in practice and modifying the method from a conceptual method to a more tangible and meaningful theory. The aim of this research is to investigate on the crisis management process in construction projects with a focus on all types of crises and made a case study of "Khuzestan province (Iran). When an incident occurs during the construction phase of a project, can that incident be immediately labeled as an unexpected event or as the occurrence of a crisis that had not been identified or properly assessed during the project planning stage, if a manager has knowledge about crisis and knowing all construction crisis category so can have an appropriate reaction and quick response, so the main goal and objective is investigation and designing a response for construction crisis based on MCDM models. Based on the above discussion the present study was taken with following objective.

i. To identify various crisis factors and obtain the essential crisis in construction industry.

ii. Proposing a framework model to weight and rate assessment of crisis factor using the Criteria Importance Through Intercriteria Correlation (CRITIC) method for refining the performance of the construction project.

Published By:

Blue Eyes Intelligence Engineering

\& Sciences Publication

(C) Copyright: All Rights Reserved "Khuzestan province (Iran). and less influential sub-crisis upon construction in

\section{LITERATURE REVIEW}

[4] Observed that there are many unwanted conditions can happen during the construction project operation, which are based on (i) natural phenomena (ii) socio-political conditions (iii) technical and complexity reasons. [5] reported there are many possible crises in construction, such as safety related occurrences, financial difficulties, serious pollution legal/contractual issues, labor relations matters (strikes, harassment, discrimination), structural difficulties and business practices to loss of central computer data or the death of a key member of an organization, and finally the conclusions that safety aspects and natural disasters are cause major problems in construction, they suggested strategic and operational planning must include dealing with able crises, and provide a core team with passable resources to manage the situation. [6] dictated the economic crisis and made it a questionnaire survey at the oil field in construction Abu Dhabi; finally, identified major factors are Supplier relationship and Crisis Prediction. [7] through a questionnaire survey by the construction industry in Turkey; and found factors that may lead to crises such as (i) government policies (ii) instable market conditions(iii)high costs of energy(iv)technological developments5-design related problems. [8] investigated the practices in the management of crisis communications in two global contexts, and they started to examine safety statistics in the construction industries in the U.S. and China, and provided guidelines for crisis management i-take responsibility ii- plan iii- know the facts iv- respond quickly v- manage press relations with journalistic intent vi- think vii- restore reputation. The major of crises involved contractual disputes, but others came from a variety of sources, quite unanticipated and in some cases rather spectacular sources such as the guerrilla attack [9]. A crisis may be a low probability event with a high impact, usually, with political, financial, social-cultural implications, research on crisis management in construction, particularly from a reactive perspective, is very limited, and literature regarding economic crisis in construction is even more limited [10].[11] Achieved by survey questionnaire of 149 construction companies, in the United States of America, which found that the top 3 crises were site accidents, contractual disputes, and damage to utility lines. [12] studied that led to the creation of a multiple criteria decision-making (MCDM) model for construction management at a case study in Turkey, they used the Analytic Hierarchy Process (AHP) method and the expert choice computer program to identify aims to create a practically useful model, observed that one of the most important problems in the construction industry is choosing the right contractor. [13] compared two industries; construction and the food and beverage-processing industries

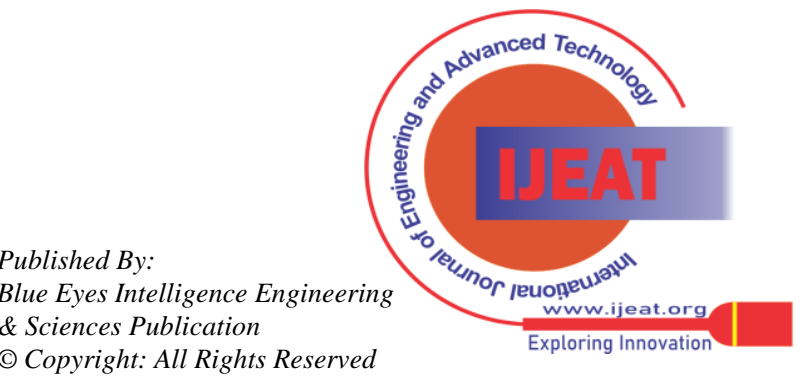


- which have behaved during a crisis period, are examined and compared; there is evidence of different business models being employed in construction and food processing. However, at this stage of our research, we have not been able to establish a relationship between the business model employed and the firms or industry performance. [14] Examined highlights the impact of the economic and financial crisis in the construction industry on European and national levels, the government failed to fulfill a series of promises including the failure to provide the 10 billion euro for investments, no taxation of reinvested profits, VAT collection from invoices, etc. The financial crisis has affected UK construction employment; they made an interpretive analysis of the data reveals shifting disparities across a number of areas, Arguably, replaced by more flexible labor markets that in turn threaten long-term prospects for the construction industry [15]. It is important to enhance knowledge on the linkage between good planning, design, and construction, and disaster prevention and management, disasters, both natural and human-caused, have been occurring with increasing frequency and effect in recent decades in many countries around the world. It is important to develop the construction industries of the poorer nations in order to equip them to manage disasters [16]. Dictated that the construction market has a tremendous impact on our Romania economy. What happens in the construction industry reflects society's demands, both from a perspective of demographic trends and especially of financing [17]. researched on carried out through questionnaire survey analysis made among the various project managers from different construction project site; observed that major factors like technical, labor, organizational, material, time, equipment, communication, financial and other factors, which are responsible for the cause of the crisis in projects, are considered [18]. The international financial crisis had an important result on the construction zone in Romania since the third quarter of 2008, to solve some other perennial problems across sectors: public procurement law review, refocus and recalibrate public investment, tax reduction types of work, labor fight black, changes in insolvency law, public investment prioritization [19]. A study on crisis preparedness of five large, international construction companies operating within Australia; the investigation suggests that their state of crisis preparedness is inadequate and unlikely to improve without external intervention; Corporate philosophies evidenced in the study do not seem to support crisis management [20] . A crisis would be likely to stimulate a period of reactionary chaos, social dislocation, and disjointedness, at least in the short term, the managerial challenge during this period would be to re-establish an element of control and co-ordination in people's activities by attempting to communicate policies that may have been developed in isolation at a senior managerial level, if at all [21]. [22] investigated that the impact of the financial crisis in the construction sector in Greece, construction is one of the sectors of the Greek economy; the stock prices of the Greek construction firms have been recorded and analyzed for the last years; except for the financial crisis, the influence of various factors on the sales of real estate and the Greek construction firms ${ }^{\text {ee }}$ stock prices have been examined and analyzed as well, they suggested the construction firms should take advantage of the proven expertise. [4] investigated the disasters during the development phase of construction projects; disasters can be based on various reasons natural, technical, moreover disasters can cause significant delays and cost rise to a project, while they can lead to construction's cancellation in cases of extensive damages or of site's natural disasters. [9] Classified various crises' sources, analyzed a number of case studies, and concluded the following set of activities for project recovery: (i) effective risk management during planning; (ii) the existence of a dual structure in the company's organization for crisis management (iii) instantaneous communication of crises between site team (iv) simultaneous operations of formally and informally developed teams. [23] Analyzed the situation of energy security in china and the concept to deal with the energy crisis, then put forward the establishment of a crisis management system to prevent and control the energy crisis, also has realistic practical value to enhance the ability of energy crisis management. [24] introduced a new framework used the multiple criteria decision making for the selection of a construction contractor for the Turkish public sector, the system recommended to be studied and three key goals have been shaped for varieties such as cost, time, and quality, they asserted this model can be rummage-sale as a decision support system by the project owners in order to identify the most appropriate contractor that will be given the contract. [25] evaluated four contractor options using CRITIC method and MAUT technique (several desirable theoretical features), while the full ranking of the contract builder options is obtained using MAUT, and then it is important to work with the right contract manufacturer to gain a competitive advantage; the issues of selecting a contractor for a textile company has been solved by CRITIC and MAUT methods. [26] developed a new formwork based on several characteristics of evaluating the product collected by weight with gray trait scores - WASPAS-G method; the proposed new WASPAS-G method is a valuable tool for more accurate decision-making for construction contractors, due to stakeholder preferences in an uncertain environment. [27] Studied the nanotechnology industry and its development in Iran; applied SWARA-WASPAS to evaluate the criteria and WASPAS utilized to evaluate and rank the alternatives. [28] presented a new method used EDAS in the Minkowski space (EDAS-M), based on CRITIC method for obtaining the objective criteria weights, and used seven unusual methods for comparing their plan to validate the efficiency and effectiveness of the proposed method. [29] Proposed a new method in modifying the (CRITIC) method, which waterfalls underneath objective methods for decisive factors weight constants. By presenting a new procedure of combination of weight constant values in the CRITIC-M method, a more complete sympathetic of data in the initial decision matrix was make possible, foremost to additional objective values of weight constants.

Blue Eyes Intelligence Engineering

\& Sciences Publication

(C) Copyright: All Rights Reserved

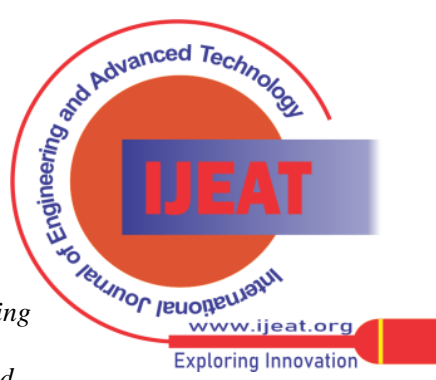




\section{An Investigation on Construction Crisis Framework Based on the CRITIC and WASPAS Methods, a Case Study; Khuzestan province (Iran)}

Therefore, the relations between information in the initial decision matrix are obtainable in a more objective solution.

[30] developed a finite element model for a ventilated brake disc is developed to numerically simulate the fatigue life and axial deflection, for data analyses and compare the various design parameter combinations, multi-criteria decision-making such as ARAS, EDAS, COPRAS, FEA, MCDM and TOPSIS are used. Used TOPSIS to optimized process parameters of the vibration-assisted turning process. The WASPAS is one of the new multi-index decision-making methods that has been accepted and working in many areas; recognized and assessed the risks of a road construction industry in Iran which the outcomes presented inaccessibility/inappropriate of barrow pits, loss of key manpower during project life cycle, employing inexperienced subcontractors are of the most important risks among identified risks [31]. performed the lossy compression algorithms' classification and with dissimilar density relations by their appropriateness intended for the aerial images based on the neutrosophic weighted aggregated sum product assessment (WASPAS) method [32].

\section{Table 1: Crisis Factors in Construction Industry}

\begin{tabular}{|c|c|c|c|}
\hline ID & Crisis Factor & Crisis Sub Factor & References \\
\hline 1 & Economic & $\begin{array}{l}\text { 1-Inflation 2-Increase Cost of Materials3-Unmanaged cash flow 4- Fluctuation } \\
\text { in prices5-Change in currency rate6-Owner low financial capacity7-Delay in } \\
\text { progress payment8-Rate of interest 9-Change in tax rate10-Project funding } \\
\text { problems11-Bankruptcies 12-Increasing amounts of bad bank loans }\end{array}$ & $\begin{array}{l}1],[5], \quad[6], \quad[13], \\
{[16],[33]-[41]}\end{array}$ \\
\hline 2 & Technical & $\begin{array}{l}\text { 13-Ineffective construction methods 14-Poor site management and supervision } \\
\text { by contractor and Inadequate contractor experience causing the technical error } \\
15 \text {-Lack of quality control process 16-Rework due to field errors committed by } \\
\text { craftsmen 17-Obsolete technology }\end{array}$ & $\begin{array}{l}\text { [1], [4], [33]-[36], } \\
\text { [38], [39], [42]. }\end{array}$ \\
\hline 3 & Natural & $\begin{array}{l}\text { 18-Earthquake } 19 \text { - Too much precipitation 20-Unexpected underground } \\
\text { condition 21- Harsh weather conditions (hot, cold) 22-Urban Floods } \\
\text { 23-Hurricanes } \\
\text { 24-Tornadoes } 25-\text {-Wunamis 26- Volcanic eruptions } \\
\text { 27-Wildfires }\end{array}$ & $\begin{array}{l}{[1],[4],[16],[37],} \\
{[38],[42] .}\end{array}$ \\
\hline 4 & Political & $\begin{array}{l}\text { 28- Corruption in government tenders 29-Wars 30-Revolutions } \\
\text { 31-Changes in laws and regulations32-Strikes called by political parties } \\
\text { 33-Instability in Governance }\end{array}$ & $\begin{array}{l}\begin{array}{l}{[1],[4],[33],[34],} \\
{[36]-[40],[42],[43] .}\end{array}\end{array}$ \\
\hline 5 & $\begin{array}{l}\text { Social and } \\
\text { cultural }\end{array}$ & $\begin{array}{l}\text { 34- Insistence on use of local Unskillful worker 35- Lack of cooperation from } \\
\text { local authorities 36-Prevent the project from continuing by local people } \\
\text { because of the project's non-compliance with religious and culture beliefs } \\
\text { 37-Inadequate support towards socio-physiological needs of employees 38- } \\
\text { Widespread lack of understanding of foreign cultures, ethnicities, and } \\
\text { languages between employees 39-Group attachment and relations } \\
40 \text {-Vandalism and robbery (insecurity) local people at site 41-Unorganized } \\
\text { corruption in local groups that related projects 42-Non-cooperation from } \\
\text { labour unions }\end{array}$ & $\begin{array}{l}{[1],[4],[7],[16],} \\
{[33],[34],[36],[38],} \\
{[39],[44],[45] .}\end{array}$ \\
\hline 6 & $\begin{array}{l}\text { Organizational } \\
\text { and } \\
\text { Management }\end{array}$ & $\begin{array}{l}\text { 43-Poor project planning ,scheduling and controlling 44-Lack of knowledge } \\
\text { Project goals 45-Management team non experience 46-Lack of periodic } \\
\text { meeting among the management, site personnel and the contractors } \\
\text { 47-Inaccurate execution plan/schedule 48- Improper project coordination } \\
\text { 49-Lack of experience of supervisor 50-Excessive bureaucracy in project } \\
\text { owned operation 51- Inadequate instructions provided by supervisor 52- Lack } \\
\text { of interaction among the site community 53-Lack of Ineffective planning and } \\
\text { scheduling of project by contractor Scheduling and controlling 54-Absence of } \\
\text { qualified personnel in key positions 55-Excessive overtime 56- Lack of timely } \\
\text { decisions and corrective actions 57-Lack of top management commitment } \\
\text { 58-Poor efficiency of supervisor or foreman 59-Lack of IT use for information, } \\
\text { coordination and interface management } 60 \text {-Poor site management and slow site } \\
\text { clearance }\end{array}$ & $\begin{array}{l}{[1],[33],[34],[40],} \\
{[42],[46],[47]}\end{array}$ \\
\hline 7 & Materials & $\begin{array}{l}\text { 61-Sudden changes in material prices 62-Delay Material delivery 63-Material } \\
\text { Storage Difficulties 64-Material theft \& damage 65-Material procurement } \\
\text { difficulties 66-Use Non-conforming material 67-Material monopoly 68- } \\
\text { Shortage of specific material 69-Low quality of raw materials }\end{array}$ & $\begin{array}{l}{[4],[16],[38],[40],} \\
{[47]-[50]}\end{array}$ \\
\hline
\end{tabular}

Published By: Blue Eyes Intelligence Engineering

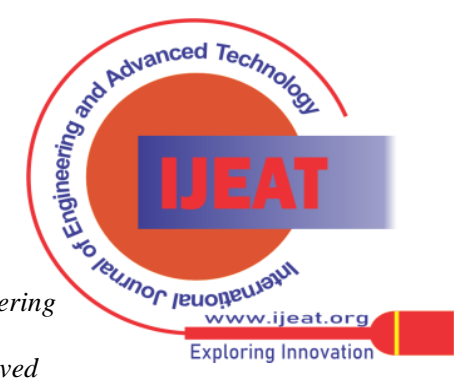




\begin{tabular}{|c|c|c|c|}
\hline 8 & $\begin{array}{l}\text { Legal and } \\
\text { contractual }\end{array}$ & $\begin{array}{l}\text { 70-Legal disputes during the construction phase 71-No specialized arbitrators } \\
\text { to help settle fast } 72 \text {-unclear some of agreement clauses } 73 \text { - Improper scope of } \\
\text { work definition in a contract } 74 \text { - Legal issues arising due to local government } \\
\text { rules and regulations } 75 \text { - Unrealistic contract duration imposed by client } \\
76 \text {-poor government judicial system for construction dispute settlement }\end{array}$ & $\begin{array}{l}{[1],[5],[33],[34],} \\
{[36],[38]-[40],[47],} \\
{[48]}\end{array}$ \\
\hline 9 & $\begin{array}{l}\text { Operational } \\
\text { and Physical }\end{array}$ & $\begin{array}{l}\text { 77-Defective work 78-Site congestion 79- Operation rework } \\
\text { 80- Poor temporary facilities at the site 81-Mistakes and Errors committed } \\
\text { during field construction at job site 82-Inaccurate site investigation } \\
\text { 83-Difficult site terrain to work 84-Poor quality control over project } 85 \text {-Old } \\
\text { and Inappropriate construction methods 86-Mistakes in soil investigation }\end{array}$ & $\begin{array}{l}\text { [1], [16], [33], [38], } \\
{[40],[42],[51]}\end{array}$ \\
\hline 10 & Logistics & $\begin{array}{l}\text { 87- Lack of Matching responsibility to authority 88-Equipment failure } \\
\text { (breakdown)and Equipment malfunctions 89-Equipment bad quality 90-Lack } \\
\text { of high-technology mechanical equipment 91-Lack of Equipment maintenance } \\
\text { 92-Delay in permits and licenses 93-Disregard of craft worker } \\
\text { suggestions/ideas 94- Inadequate experience of staff 95- Lack of team spirit } \\
\text { among craftsmen 96- Supervisor absenteeism 97-Inaccessibility new } \\
\text { technology 98- Poor performance of subcontractors 99-Lack of competent } \\
\text { subcontractors/suppliers 100- Low ability of contractor to provide imported } \\
\text { material 101- Wrong choice of contractor or consultant 102- Lack of database } \\
\text { in estimating activity duration and resources 103- sudden death of a key } \\
\text { member of an organization (construction project) }\end{array}$ & $\begin{array}{l}{[1],[5],[37],[40],} \\
{[47]}\end{array}$ \\
\hline 11 & Design & $\begin{array}{l}\text { 104-Defective design 105-Not coordinated design 106-Inaccurate quantities } \\
\text { for design 107-Awarding the design to unqualified designers 108- Design } \\
\text { errors made by designers 109-DesignsImpractical 110-Complexity of design } \\
\text { 111-Frequent revision and change of design, resulting in additional rework } \\
\text { 112-Timely unavailability of drawings at the worksite } 113-S l o w \text { response on } \\
\text { doubts arising from the drawings } 114 \text { - Over-design increasing the overall cost } \\
\text { 115-Lack of standardization in design }\end{array}$ & [1], [37], [40], [50] \\
\hline 12 & Environmental & $\begin{array}{l}\text { 116-Difficulty to access the site 117-Operation with high potential soil erosion } \\
\text { 118-Archeological survey not done 119-Lack of Geo-technical investigation } \\
\text { 120-Landscape Alteration due to many constructions 121-Construction } \\
\text { operations with Vegetation Removal and destroying of small rural habitats }\end{array}$ & $\begin{array}{l}\text { [1], [33], [37], [43], } \\
{[52]-[54]}\end{array}$ \\
\hline 13 & $\begin{array}{l}\text { Market and } \\
\text { Real estates }\end{array}$ & $\begin{array}{l}\text { 122-Instable market and real estate, Unstable construction market conditions } \\
\text { 123-Restrictive legislation and lack of transparency in transactions 124- } \\
\text { undeclared transactions, mainly due to high stamp duty rates } 125 \text { - Increase in } \\
\text { litigation between landlords and tenants 126-Existence of a housing bubble } \\
\text { 127-Lack of the rent control act 128-Rumors in the real estate market } 129 \text { - } \\
\text { Falls in real estate prices and various expectations. }\end{array}$ & $\begin{array}{lc}{[5],} & {[7],} \\
{[55]-[58]} & {[34],}\end{array}$ \\
\hline 14 & $\begin{array}{l}\text { Workplace } \\
\text { Violence }\end{array}$ & $\begin{array}{l}\text { 130-Slow land expropriation due to resistance from occupant's owner } \\
\text { 131-Terrorist attacks/man-made disaster 132- Involvement during } \\
\text { construction stage 133-Local people obstruction and blockage 134-Conflicts } \\
\text { between workers and employees at the site 135-unfair behavior of the parties to } \\
\text { a construction contract agreement 136-Disputes with consultants/ owner/ } \\
\text { contractor causing stoppage of work }\end{array}$ & $\begin{array}{l}\begin{array}{l}{[36],} \\
{[59]-[61]}\end{array} \\
\end{array}$ \\
\hline 15 & Labour Issue & $\begin{array}{l}\text { 137-Strikes, harassment, discrimination of labour 138- Lack of skilled } \\
\text { operators for specialized equipment 139-Lack of labour experience } \\
\text { 140-Labour disloyalty 141-Lack of competition between labour employment } \\
\text { 142-Increase of labourer age 143-Labour absenteeism 144-Labour personal } \\
\text { problems 145-Misunderstanding between labour/ superintendents } \\
\text { 146-Payment delay to labour 147-Lack of labour recognition programs } \\
\text { 148-Working hours' restrictions 149-Lack of places for eating and relaxation } \\
\text { 150-Lack of training sessions for Specialist labour 151-Lack of Labour } \\
\text { availability 152-Drop in Labour productivity }\end{array}$ & $\begin{array}{l}{[4],[5],[36]-[38],} \\
{[42],[49]-[51],[62]}\end{array}$ \\
\hline
\end{tabular}

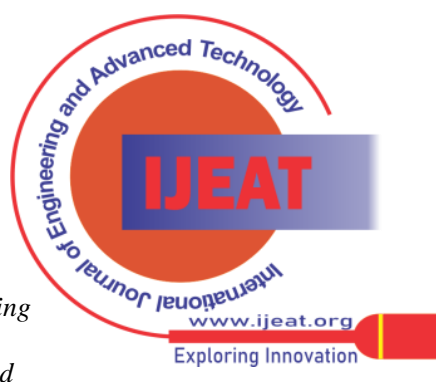




\begin{tabular}{|c|c|c|c|}
\hline 16 & Safety & $\begin{array}{l}\text { 153-Accidents such as Power tool and machinery accidents / Scaffolding } \\
\text { accidents /Ladder accidents / Falls / Struck by object / Caught-in/between /Slip } \\
\text { and falls 154-Violation of safety precautions and requirements 155- Unsafe } \\
\text { working operational conditions }\end{array}$ & $\begin{array}{l}{[4],[5],[16],[37],} \\
{[47],[49],[50],[55],} \\
{[63]}\end{array}$ \\
\hline 17 & Insurance & $\begin{array}{l}\text { 156-Not covering all risks in insurance 157- Contradiction in insurance text } \\
\text { and principle of coverage 158- Not insuring part of the building under } \\
\text { construction by the Insured 159- Not Insurance coverage of all employees, } \\
\text { workers and third parties by the insurance company or Insurer 160- Overhead } \\
\text { costs of insurance }\end{array}$ & [48], [52] \\
\hline 18 & Pollution & $\begin{array}{l}\text { 161-Water pollution 162-Dust generation with construction machinery } \\
\text { 163-Air pollution 164-Waste generation 165-Noise Pollution 166-Land } \\
\text { pollution 167- Emissions of hazardous waste with construction operations 168- } \\
\text { Crisis Landfill pollution occurs through the construction process }\end{array}$ & [5], [37], [53] \\
\hline 19 & Maintenance & $\begin{array}{l}\text { 169-Lack of Knowledge and Expertise on Maintenance Aspects 170-late } \\
\text { troubleshooting 171-Poor and improper building maintenance }\end{array}$ & [16], [50], [64] \\
\hline 20 & Energy & $\begin{array}{l}\text { 172-Excessive energy consumption duration of construction operations } 173- \\
\text { High costs of energy 174-Excessive consumption of non-renewable resource }\end{array}$ & [7], [23], [52], [54] \\
\hline
\end{tabular}

III.

\section{SOLUTION METHODOLOGY}

Many studies have analyzed crises in the construction industry and some of them have produced conceptual frameworks, but in the "Khuzestan province (Iran) "scenario, additional research is needed to identify the most probability of occurrence (most effect) over the construction crisis in "Khuzestan province (Iran) ". construction industry of "Khuzestan province (Iran) "e need to develop specific capabilities to overcome difficult situations and to gain a competitive advantage, and one approach is to use the decision making analysis and statistical and mathematical analysis such as MCDM for identifying and ranking all crisis factor which has relevant to the construction industry, that plays a major role in improving managers' knowledge of the construction industry performance measures. The design of this study is cross-sectional because at this point in time (2014-2020), experts from top levels (of two categories of owner and contractor are selected and their knowledge and experience are evaluated. This study aims to establish a research framework to address the above-stated need and to guide managers in selecting and concentrating on the construction crisis factor and associated MCDM practices, since the current, no proper work confirms which focus on the crisis in "Khuzestan province (Iran) construction projects this study proposes to:

i. Identify the general construction crisis from existing literature.

ii. Conduct a questionnaire-based survey to obtain the essential crisis factors in construction projects by getting feedback from experts.

iii. Conduct a questionnaire-based survey with top experts from "Khuzestan province (Iran) construction organization as respondents to obtain a level of impact each sub factors based on the rating of its impact the second list, and then categorize them under the performance measures and for Preparation Executives for Exposure with the crisis.

iv. Using Criteria Importance through Inter criteria Correlation (CRITIC) method to weighting crisis factors. v. Ranking the influential sub crisis factors from the all sub crisis list and provide a single list without considering the initial list crisis through WASPAS model.

The solution methodology applied for the present study is to use the Multi-Criteria Decision Making (MCDM) such as WASPAS to prioritize factors upon construction crisis criteria, and using Criteria Importance through Inter criteria Correlation (CRITIC) method to weight and rate assessment of crisis factor finally applying correlation tests for verifying the weighted and ranked parameters. The first questionnaire was submitted to the seven experts from the "Khuzestan province (Iran) construction organization as respondents, we hold discussions through personal meetings, e-mails, and try to make them understand the need for our study and its usefulness, We requested experts that identify the essential factors and remove the equivalent factors and even we allowed them to add new factors to our list according to the knowledge and experience, through detailed interactive sessions with that seven experts identified the 174 shortlisted sub-factor from 222 the general construction crisis and then classified under the 20 main factor, after the demystify sub factors only submit the now questionnaire-based survey, to the experts in the field of "Khuzestan province (Iran) construction, some of the probabilistic respondents. After completing the design of the questionnaire, was translated into Persian (Farsi). Although the majority of the managers and engineers involved in construction projects know English, it was decided to translate them to Persian because they contain some specific words in order to ensure everyone understands the content completely and any mistranslation by participants is prevented. The researcher applying two ways to send the questionnaires; first using Google Form multiple-choice option and questionnaires sent by Email as an Excel sheet to the companies, government organizations, and ask them to print out and respond to the questionnaire and send it back to the researcher. Once the questionnaire was create, the questionnaire submitted to the top managerial level




experts such as contractors as well as owners, and telephonic interviews to make them understand the need of the study.

The experts had construction fields with more than ten years of experience, in the construction project of "Khuzestan province (Iran) ". A profile of the Percent of participant experts are shown in Table 2, which are the government organization as the owner and the private construction companies and contractors who are active in the construction project of "Khuzestan province (Iran) ".

Table 2: Percent of Participant Experts

\begin{tabular}{|l|l|l|l|}
\hline Experts job & $\begin{array}{l}\text { Number of } \\
\text { questionnaire }\end{array}$ & $\begin{array}{l}\text { Number of } \\
\text { responses }\end{array}$ & $\begin{array}{l}\text { Percent } \\
\text { of } \\
\text { responses }\end{array}$ \\
\hline Contractor & 150 & 97 & $64.7 \%$ \\
\hline $\begin{array}{l}\text { Government } \\
\text { owner }\end{array}$ & 30 & 21 & $70 \%$ \\
\hline Total & 180 & 118 & $65.6 \%$ \\
\hline
\end{tabular}

Once the data were collected, they had to be analyzed and preferably illustrated in diagrams, charts, and tables. After collecting the questionnaires from participants, a codebook was prepared to comprise distinctive codes for different sections of it. Data written and marked in each questionnaire was entered into Microsoft Office Excel according to the codebook and using the unique ID from 1 to 174 which was provided for them before distributing to respondents. Therefore, quantitative data were analyzed using Microsoft Office Excel and SPSS (Statistical Package for Social Science). The level of criticality of the crisis in construction projects, the level of effectiveness of proposed mitigation strategies, and the opinion of participants about various aspects of construction projects were evaluated.

\section{CRITIC Method}

The MCDM models have always been associated to two factors and issues, one is the weighting of criteria and the other is the ranking of options. These two categories are complementary to each other, sometimes by one method and sometimes by a combination of methods. In this method, the data analyzed based on the degree of interference and conflict between the factors or criteria. CRITIC (Criteria Importance through Intercriteria Correlation) method is one of the weighting methods, which determines objective weights for criteria. CRITIC method was proposed by Diakoulaki et al. in 1995; it uses correlation analysis to find out the contrasts between criteria; in this method, the decision matrix is evaluated and the standard deviation of normalized criterion values by columns and the correlation coefficients of all pairs of columns are used to determine the criteria contrast [65]. These parameters represent the degree of difference in the relevant standard values. The CRITIC method steps 1 to 3 as follows Step 1: The decision matrix $\mathrm{X}$ is formed; it shows the performance of different alternatives with respect to various criteria.
$\boldsymbol{X}=\left[\begin{array}{cccc}x_{11} & x_{12} & \ldots & x_{1 m} \\ x_{21} & x_{22} & \ldots & x_{2 m} \\ \ldots & \ldots & \ldots & \ldots \\ x_{n 1} & x_{n 2} & \ldots & x_{n m}\end{array}\right]$

Step 2: Decision matrix is normalized data using the equation 1:

$r_{i j}=\frac{x_{i j}-\min \left(x_{i j}\right)}{\max \left(x_{i j}\right)-\min \left(x_{i j}\right)}$

$r_{i j} \quad$ Normalized performance value

$X_{i j} \quad$ Each sub-factors number

Step 3: While determining the criteria weights, both standard deviation of the criterion and its correlation between other criteria are included.

$C_{j}=\sigma_{j} \sum_{j=1}^{n}\left(1-r_{j}\right)$

$C_{j} \quad$ Quantity of information contained

\section{$\sigma_{j} \quad$ Standard deviation}

For determine the importance of each sub-factor used equation number 3.

$$
W_{j}=\frac{c_{j}}{\sum_{j=1}^{n} c_{j}}
$$

\section{WASPAS Method}

WASPAS is a comparatively new MCDM method. The WASPAS assimilates well-known aggregation operators, which are WSM and WPM. [66] argue that accuracy of the integrated model is higher than WSM and WPM. The basic steps of the WASPAS method can be given as follows: Normalization of the decision matrix: The linear normalization of the decision matrix is performed by using equations (4)-(5) for beneficial and non-beneficial attributes, respectively:

$r_{i j}=\frac{x_{i j}}{\max \left(x_{i j}\right)}$
$r_{i j}=\frac{\max \left(x_{i j}\right)}{x_{i j}}$

Calculating relative importance of sub factors: In the WASPAS method, one of the two aggregation operators is the WSM. The WSM method is highly popular and well-accepted MADM approach because of its practicality. According to the WSM, the relative importance of the ith sub factors is calculated as:

$\Phi^{1}=\sum_{j-1}^{n} x_{i j}^{n} w_{j}$

where $w j$ is the relative importance of the $j t h$ criterion. Moreover, based on the WPM, the relative importance of ith sub factors is calculated as:

$\Phi^{2}=\prod_{j-1}^{n} x_{i j j}^{x} w_{j}$

The additive and multiplicative forms of aggregation are utilized in an integrated way to increase the ranking accuracy. The ranking of the ith sub factors is performed as:

$Q_{i}=\risingdotseq Q_{i}^{1}+(1-\doteqdot) Q_{i}^{2}$

(8)

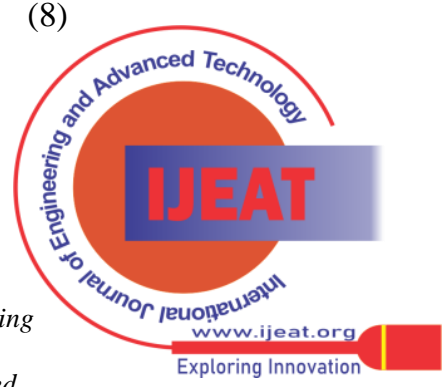




\section{RESULTS AND DISCUSSION}

Whereas the various crisis factors analyzed and how they help the construction manager through the MCDM to enhance its capabilities; identifying the crises in construction project and contributed the necessary proof for relationship their importance, from the MCDM perspective, prioritization weights and assessment of the crisis in "Khuzestan province (Iran) "e construction projects. Hence,

identifying the crisis factors in construction projects help managers to successfully compilation of projects for an effective sustainable outcome. The ranking based on the WASPAS method and weights of the specific crisis factors, along with the corresponding CRITIC method weights under each performance measure criteria, are shown in Table 3. The following sections provide an overview of the results obtained for each of the performance measure categories. A brief description of the main factors practices to be considered to develop these sub-factors is presented. From Table 3 it is observed that the most influential crisis in Khuzestan construction industry according to WASPAS method is inflation with total score 41.2725 , the second sub crisis in Khuzestan construction industry is sudden changes in material prices with total score 40.9062, and the third sub crisis in Khuzestan construction industry is increase cost of materials with score 40.4802, and respectively, change in currency rate equals 39.1199 , fluctuation in prices equals 38.6178, project funding problems equals 38.2102, delay in progress payment equals 36.7684, Rate of interest equals 35.5254 , rumors in the real estate market equals 35.4754 , defective work equals 35.1090. However, the ranking and results of the most influential sub-crisis in Khuzestan construction projects are shown in Tables 3.

Table 3: Most Influential Sub-Crisis in Construction Projects

\begin{tabular}{|l|l|l|l|l|l|l|c|}
\hline ID & Crisis Factor & Ideal & WSM & $\begin{array}{l}\text { CRITIC } \\
\text { Weight }\end{array}$ & WPM & QI & Rank \\
\hline 1 & Inflation & 77.7 & 81.6 & 0.00763 & 0.9449 & 41.2725 & 1 \\
\hline 61 & Sudden changes in material prices & 75.6 & 80.9 & 0.00758 & 0.9124 & 40.9062 & 2 \\
\hline 2 & Increase cost of materials & 66.5 & 80 & 0.0074 & 0.9603 & 40.4802 & 3 \\
\hline 5 & Change in currency rate & 58.8 & 77.3 & 0.00710 & 0.9398 & 39.1199 & 4 \\
\hline 4 & Fluctuation in prices & 44.1 & 76.3 & 0.00749 & 0.9357 & 38.6178 & 5 \\
\hline 10 & Project funding problems & 51.8 & 75.5 & 0.00689 & 0.9205 & 38.2102 & 6 \\
\hline 7 & Delay in progress payment & 40.6 & 72.6 & 0.00657 & 0.9368 & 36.7684 & 7 \\
\hline 6 & Owner low financial capacity & 30.8 & 70.1 & 0.00651 & 0.9509 & 35.5254 & 8 \\
\hline 128 & Rumors in the real estate market & 32.9 & 70 & 0.00629 & 0.9507 & 35.4754 & 9 \\
\hline 77 & Defective work & 30.8 & 69.3 & 0.00632 & 0.9181 & 35.1090 & 10 \\
\hline 122 & $\begin{array}{l}\text { Instable market and real estate, Unstable } \\
\text { construction market conditions }\end{array}$ & 37.8 & 69.2 & 0.00638 & 0.9490 & 35.0745 & 11 \\
\hline 28 & Corruption in government tenders & 25.9 & 68.4 & 0.00659 & 0.9276 & 34.6638 & 12 \\
\hline 127 & Lack of the rent control act & 39.9 & 67.4 & 0.00642 & 0.9183 & 34.1591 & 13 \\
\hline 126 & Existence of a housing bubble & 24 & 67.1 & 0.00620 & 0.9891 & 34.0446 & 14 \\
\hline 97 & Inaccessibility new technology & 28.2 & 65 & 0.00586 & 0.9664 & 32.9832 & 15 \\
\hline 92 & Delay in permits and licenses & 20.3 & 64.3 & 0.00571 & 0.9541 & 32.6270 & 16 \\
\hline 123 & $\begin{array}{l}\text { Restrictive legislation and lack of transparency in } \\
\text { transactions }\end{array}$ & 24.6 & 64.3 & 0.00668 & 0.9086 & 32.6043 & 17 \\
\hline 93 & Disregard of craft worker suggestions/ideas & 27.6 & 63.2 & 0.00573 & 0.9446 & 32.0723 & 18 \\
\hline 3 & Unmanaged cash flow & 25.8 & 62.8 & 0.00605 & 0.9368 & 31.8684 & 19 \\
\hline 160 & Overhead costs of insurance & 22.4 & 62.4 & 0.00660 & 0.9554 & 31.6777 & 20 \\
\hline
\end{tabular}

From Table 4 it is observed that the less influential crisis in the Khuzestan construction industry according to WASPAS method is tsunamis and volcanic eruptions after that revolutions, war, and hurricanes then terrorist attacks/man-made disaster and sudden death of a key member of an organization (construction project), wildfires, strikes called by political parties and tornadoes, and respectively conflicts between workers and employees at the site, Falls in

real estate prices and various expectations, unorganized corruption in local groups that related projects, unexpected underground condition. However, the ranking and results of the less influential sub-crisis in Khuzestan construction projects are shown in Tables 4.

Published By:

Blue Eyes Intelligence Engineering

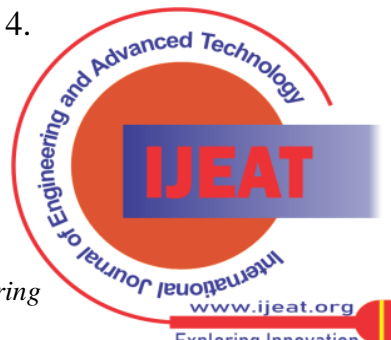


Table 4: Less Influential Sub-Crisis in Construction Projects

\begin{tabular}{|c|c|c|c|c|c|c|c|}
\hline ID & Crisis Factor & Ideal & WSM & $\begin{array}{l}\text { CRITIC } \\
\text { Weight }\end{array}$ & WPM & QI & Rank \\
\hline 136 & $\begin{array}{l}\text { Disputes with consultants/ owner/ contractor } \\
\text { causing stoppage of work }\end{array}$ & 11.2 & 35.3 & 0.00475 & 0.9616 & 18.1308 & 155 \\
\hline 117 & Operation with high potential soil erosion & 12 & 34.7 & 0.00510 & 0.9668 & 17.8334 & 156 \\
\hline 36 & $\begin{array}{l}\text { Prevent the project from continuing by local } \\
\text { people because of the project's non-compliance } \\
\text { with religious and culture beliefs }\end{array}$ & 11 & 34.3 & 0.00468 & 0.9769 & 17.6384 & 157 \\
\hline 19 & Too much precipitation & 16.4 & 34.3 & 0.00594 & 0.9657 & 17.6328 & 158 \\
\hline 132 & Involvement during construction stage & 10 & 34.1 & 0.00501 & 0.9680 & 17.5340 & 159 \\
\hline 167 & $\begin{array}{l}\text { Emissions of hazardous waste with construction } \\
\text { operations }\end{array}$ & 13.8 & 32.5 & 0.00612 & 0.9465 & 16.7233 & 160 \\
\hline 134 & $\begin{array}{l}\text { Conflicts between workers and employees at the } \\
\text { site }\end{array}$ & 12 & 31.6 & 0.00594 & 0.9557 & 16.2778 & 161 \\
\hline 129 & Falls in real estate prices and various expectations. & 9.1 & 31 & 0.00408 & 0.9836 & 15.9918 & 162 \\
\hline 41 & $\begin{array}{l}\text { Unorganized corruption in local groups that related } \\
\text { projects }\end{array}$ & 6.9 & 30.2 & 0.00661 & 0.9772 & 15.5886 & 163 \\
\hline 20 & Unexpected underground condition & 8.2 & 26.5 & 0.00465 & 0.9890 & 13.7445 & 164 \\
\hline 24 & Tornadoes & 9.6 & 26.5 & 0.00513 & 0.9824 & 13.7412 & 165 \\
\hline 32 & Strikes called by political parties & 6.8 & 23.9 & 0.00382 & 0.9861 & 12.4431 & 166 \\
\hline 27 & Wildfires & 9.6 & 23.2 & 0.00605 & 0.9677 & 12.0838 & 167 \\
\hline 103 & $\begin{array}{l}\text { Sudden death of a key member of an organization } \\
\text { (construction project) }\end{array}$ & 7.2 & 22.8 & 0.00578 & 0.9547 & 11.8774 & 168 \\
\hline 131 & Terrorist attacks/man-made disaster & 7.8 & 20.5 & 0.00591 & 0.9415 & 10.7208 & 169 \\
\hline 23 & Hurricanes & 8.3 & 19.5 & 0.00534 & 0.9606 & 10.2303 & 170 \\
\hline 29 & Wars & 9.4 & 14.8 & 0.00446 & 0.9701 & 7.8850 & 171 \\
\hline 30 & Revolutions & 10.7 & 13.4 & 0.00472 & 0.9794 & 7.1897 & 172 \\
\hline 25 & Tsunamis & 11.8 & 11.8 & 0 & 1 & 6.4 & 173 \\
\hline 26 & Volcanic eruptions & 11.8 & 11.8 & 0 & 1 & 6.4 & 173 \\
\hline
\end{tabular}

The result of crisis effects rating, from Figure 1 seen that the most crisis effects rating in the Khuzestan construction industry is the economic crisis, followed by market and real estates, and then insurance, maintenance, logistics, materials, energy, organizational and management, after that, respectively, design, technical, safety. The crisis effect rating, for overall result in the Khuzestan construction industry show in Figure 1.

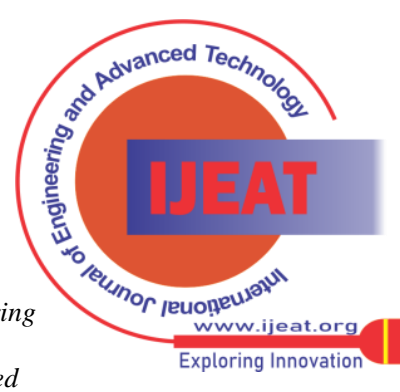


An Investigation on Construction Crisis Framework Based on the CRITIC and WASPAS Methods, a Case Study; Khuzestan province (Iran)

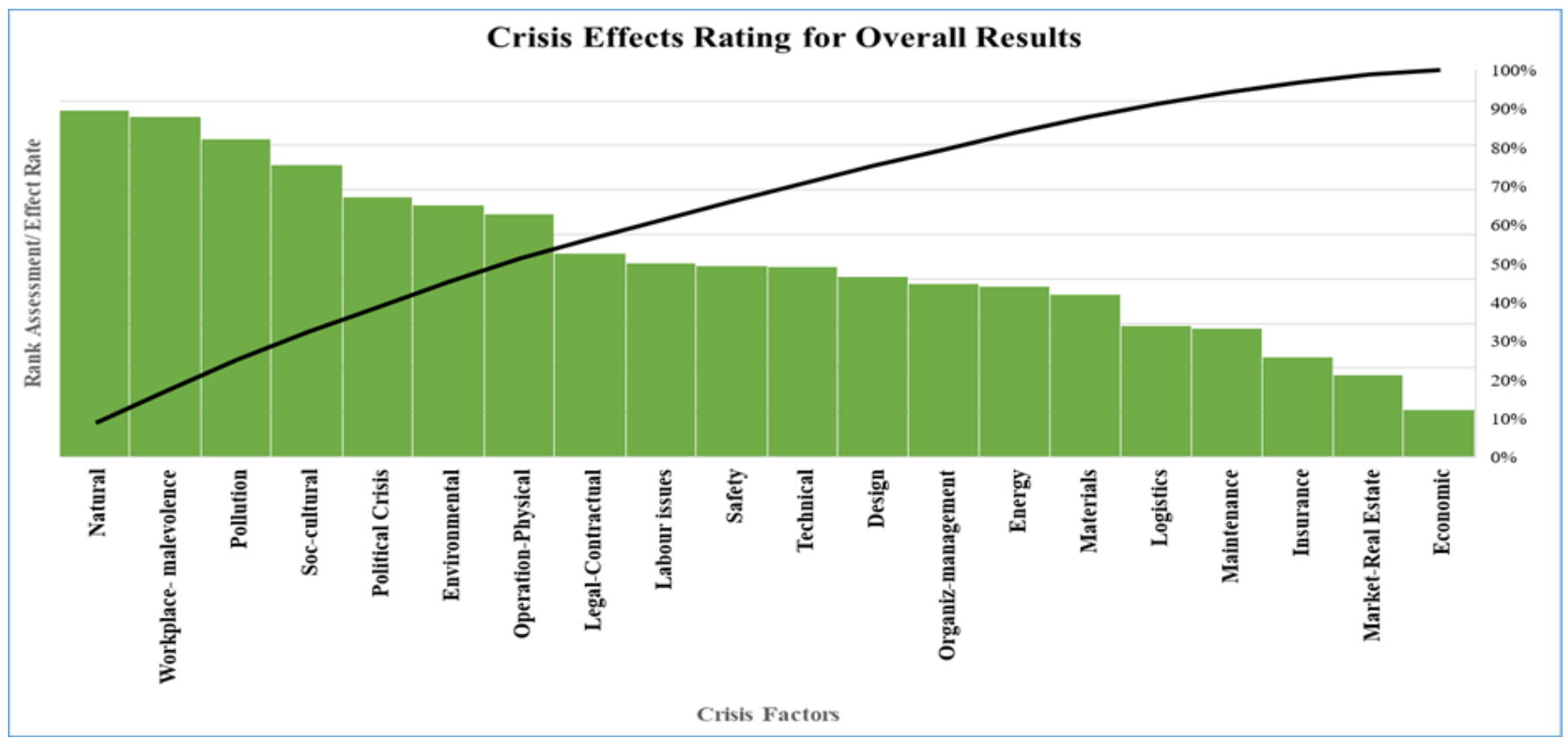

Figure 1: Crisis Effects Rating for Overall Results

\section{CONCLUSIONS}

Based on the results obtained from the analysis, the following conclusions have been drawn. There are 174 sub-crisis were collected based on the literature and field investigation and

experts opinion but determining which sub crisis would highest effect on construction was a more difficult question, with support from published literature and the opinions of experts, the crises were grouped under 20 categories of main factors measures. A survey asked the experts to rank each sub crisis on a seven-point scale; their responses obtained of the crisis effects rating. Considering the 20 main crisis, it could be seen that the most impact rank in the Khuzestan construction industry were the economic crises, followed by market and real estate crises, then insurance, maintenance, logistics, and materials crises. The first step for reducing the crisis in the construction industry is to understand the root causes of the crisis; the main objective of this study was to identify the most influential crisis (the highest degree of effect of crisis) in the Khuzestan construction industry. From overall results, it was found Inflation and Sudden changes in material prices is the most influential of crisis in the Khuzestan construction industry. It is worth mentioning that the ranking according to WASPAS method and weights of the specific crisis factors, along with the corresponding CRITIC method shows that the tsunamis and volcanic eruptions are not any effects on the Khuzestan construction industry. The impact rank of the crisis is specified according to the country or location of the project or the type of the project; evaluating the opinion of all the participants about the crisis, it could be ascertained that the level of criticality for the construction projects ${ }^{\text {ee }}$ crisis in "Khuzestan province Iran" is more than intermediate. Moreover, the dissatisfaction of the owners and contractors with the crisis management knowledge of the parties and the communication between them was understood. It appears to be a great agreement on crisis causes between contractors /government experts with Spearman's correlation coefficient equals (0.898) almost reaching the total agreement (1). Identify the crisis is the main part of crisis management, so this study helps construction crisis managers and all stakeholders to achieve sustainable development in construction projects. It can be concluded that the managers cannot manage the crisis unless identifying all factors of the crisis in the construction industry; the findings and procedures of the current study can be taken into consideration across Iran and other nations. Further scope work can be investigated in other countries who are involved in this crisis and can be analyzed with different tools like BCM, BWM, and also identify the effect of new crises such as pandemic; and contractor's perspective but also other stakeholder perspectives, in order to provide the opportunity for carrying out comparative studies. Any research may include some limitations due to different reasons especially the limited period for conducting this kind of study; one of the new models for determining weight coefficients of criteria in MCDM models is the full consistency method (FUCOM), and the researchers wanted to use this method but (FUCOM) software supported only 99 criteria so we have to use CRITIC method, this is a major and specific limitation of this study.

\section{ACKNOWLEDGMENT}

This research was conducted as part of the corresponding author Ph.D. in Department of Civil Engineering, UCE, Osmania University, Telangana State Any opinions, findings, and conclusions expressed in this publication are those of the author and necessarily reflect the current views and policies. The authors would like to thank the experts who gave the responses. The authors would like to thank the experts who gave the responses.

\section{REFERENCES}

1. M. Loosemore, "Crisis management in construction projects," 2000

2. S. J. Venette, "Risk communication in a high reliability organization," Ann Arbor, MI UMI Proquest Inf. Learn., 2003.

Published By:

Blue Eyes Intelligence Engineering

\& Sciences Publication

(C) Copyright: All Rights Reserved




3. S. Sahin, S. Ulubeyli, and A. Kazaza, "Innovative crisis management in construction: Approaches and the process," Procedia-Social Behav. Sci., vol. 195, pp. 2298-2305, 2015.

4. L. G. Anthopoulos, E. Kostavara, and J.-P. Pantouvakis, "An effective disaster recovery model for construction projects," Procedia-Social Behav. Sci., vol. 74, pp. 21-30, 2013.

5. J. G. Gunning and J. I. C. Hanna, "The application of risk management principles to crisis management in construction," in 17th Annual ARCOM Conference, 2001, pp. 5-7.

6. S. S. Babu and D. B. Sudhakar, "Construction project management during economic crisis,” Int. J. Manag., vol. 7, no. 7, 2016.

7. E. Öcal, E. L. Oral, and E. Erdis, "Crisis management in Turkish construction industry," Build. Environ., vol. 41, no. 11, pp. 1498-1503, 2006.

8. S. Sokuvitz and S. Perkins, "Managing crisis communications in the construction industries: A pedagogical approach," Int. J. Educ. Soc. Sci., vol. 2, no. 1, pp. 27-35, 2015.

9. M. Hällgren and T. L. Wilson, "The nature and management of crises in construction projects: projects-as-practice observations,” Int. J. Proj. Manag., vol. 26, no. 8, pp. 830-838, 2008.

10. E. Sfakianaki, T. Iliadis, and E. Zafeiris, "Crisis management under an economic recession in construction: the Greek case," Int. J. Manag. Decis. Mak., vol. 14, no. 4, pp. 373-389, 2015.

11. J. J. Reid, Crisis of the Ottoman Empire: prelude to collapse 1839-1878, vol. 57. Franz Steiner Verlag, 2000.

12. S. Erdoğan, M. K. Balki, S. Aydın, and C. Sayin, "The best fuel selection with hybrid multiple-criteria decision making approaches in a CI engine fueled with their blends and pure biodiesels produced from different sources,” Renew. Energy, vol. 134, pp. 653-668, 2019.

13. M. Kastelan-Mrak, D. Sokolic, and N. Vretenar, "Comparing the performance of two industries during the crisis," Ekon. horizonti, vol. 18, no. 3, pp. 261-275, 2016.

14. T. Nistorescu and C. Ploscaru, "impact of economic and financial crisis in the construction industry.," Manag. Mark. J., vol. 8, no. 1, 2010.

15. P. W. Chan and S. McCabe, "Emerging disparities: exploring the impacts of the financial crisis on the UK construction labour market," in Proceedings of the 26th ARCOM Annual Conference, Leeds, 2010, pp. 6-8.

16. G. Ofori, "Construction industry development for disaster prevention and response," in Proceedings of i-Rec conference on improving post-disaster reconstruction in developing countries, 2002, pp. 23-25.

17. C. Dinu, "Marketing on the construction market in a economic crisis," Ann. Univ. Apulensis Ser. Oeconomica, vol. 2, no. 11, pp. 1-52, 2009.

18. J. Raj Prasad and V. Thamilrasu, "Role of crisis management in construction projects,” Int. J. Eng., vol. 7, no. 2.12, pp. 451-453, 2018.

19. C. Simion-Melinte, "Strategic Options To Minimize The Effects Of The Economic Crisis On The Construction Sector In Romania," in proceedings of the international management conference, 2013, vol. 7, no. 1, pp. 292-298.

20. M. Loosemore and M. M. M. Teo, "The crisis management practices of Australian construction companies," Constr. Econ. Build., vol. 2, no. 2, pp. 15-26, 2002.

21. C. M. Pearson and I. I. Mitroff, "From crisis prone to crisis prepared: A framework for crisis management," Acad. Manag. Perspect., vol. 7, no. 1, pp. 48-59, 1993.

22. M. Skordoulis, G. Sarvanaki, and M. Chalikias, "The impact of the economic crisis on the construction sector in Greece," in International Scientific Conference eRA, 2014, vol. 9.

23. Y. Qingchun, "A Study of Management System Based on Energy Crisis," in IOP Conference Series: Earth and Environmental Science, 2018, vol. 153, no. 3, p. 32001.

24. Y. I. Topcu, "A decision model proposal for construction contractor selection in Turkey," Build. Environ., vol. 39, no. 4, pp. 469-481, 2004.

25. E. A. Adalı and A. T. Işık, "CRITIC and MAUT methods for the contract manufacturer selection problem," Eur. J. Multidiscip. Stud., vol. 2, no. 5, pp. 93-101, 2017.

26. E. K. Zavadskas, Z. Turskis, and J. Antucheviciene, "Selecting a contractor by using a novel method for multiple attribute analysis: Weighted Aggregated Sum Product Assessment with grey values (WASPAS-G),” Stud. Informatics Control, vol. 24, no. 2, pp. 141-150, 2015.

27. M. R. Ghorshi Nezhad, S. H. Zolfani, F. Moztarzadeh, E. K. Zavadskas, and M. Bahrami, "Planning the priority of high tech industries based on SWARA-WASPAS methodology: The case of the nanotechnology industry in Iran,” Econ. Res. istraživanja, vol. 28, no. 1, pp. 1111-1137, 2015.
28. E. K. Zavadskas, R. Stevic, Z. Turskis, and M. Tomaševic, "A novel extended EDAS in Minkowski Space (EDAS-M) method for evaluating autonomous vehicles," Stud. Informatics Control, vol. 28, no. 3, pp. 255-264, 2019.

29. M. Žižović, B. Miljković, and D. Marinković, "Objective methods for determining criteria weight coefficients: A modification of the CRITIC method," Decis. Mak. Appl. Manag. Eng., vol. 3, no. 2, pp. 149-161, 2020.

30. N. Maheshwari, J. Choudhary, A. Rath, D. Shinde, and K. Kalita, "Finite Element Analysis and Multi-criteria Decision-Making (MCDM)-Based Optimal Design Parameter Selection of Solid Ventilated Brake Disc,” J. Inst. Eng. Ser. C, pp. 1-11, 2021.

31. M. Badalpur and E. Nurbakhsh, "An application of WASPAS method in risk qualitative analysis: a case study of a road construction project in Iran,” Int. J. Constr. Manag., pp. 1-9, 2019.

32. R. Bausys and G. Kazakeviciute-Januskeviciene, "Qualitative Rating of Lossy Compression for Aerial Imagery by Neutrosophic WASPAS Method," Symmetry (Basel)., vol. 13, no. 2, p. 273, 2021.

33. A. Kaklauskas et al., "Crisis management in construction and real estate: Conceptual modeling at the micro-, meso-and macro-levels,' Land use policy, vol. 28, no. 1, pp. 280-293, 2011.

34. A. Kaklauskas, E. K. Zavadskas, A. Bagdonavicius, L. Kelpsiene, D. Bardauskiene, and V. Kutut, "Conceptual modelling of construction and real estate crisis with emphasis on comparative qualitative aspects description,” Transform. Bus. Econ., vol. 9, no. 1, pp. 42-61, 2010.

35. M. Kapelko, A. O. Lansink, and S. E. Stefanou, "Assessing dynamic inefficiency of the Spanish construction sector pre-and post-financial crisis,” Eur. J. Oper. Res., vol. 237, no. 1, pp. 349-357, 2014.

36. S. N. Patil, A. P. Mehendale, D. R. Patil, P. M. Patil, and M. B. Patil, "Crisis Management in Housing Project in Around Kolhapur City," Int. J. Eng. Sci., vol. 14970, 2017.

37. M. S. B. A. Abd El-Karim, O. A. Mosa El Nawawy, and A. M. Abdel-Alim, "Identification and assessment of risk factors affecting construction projects," HBRC J., vol. 13, no. 2, pp. 202-216, 2017.

38. P. O. Akanni, A. E. Oke, and O. A. Akpomiemie, "Impact of environmental factors on building project performance in Delta State, Nigeria," HBRC J., vol. 11, no. 1, pp. 91-97, 2015.

39. E. E. Ameyaw and A. P. C. Chan, "Evaluation and ranking of risk factors in public-private partnership water supply projects in developing countries using fuzzy synthetic evaluation approach," Expert Syst. Appl., vol. 42, no. 12, pp. 5102-5116, 2015.

40. R. F. Aziz and A. A. Abdel-Hakam, "Exploring delay causes of road construction projects in Egypt,” Alexandria Eng. J., vol. 55, no. 2, pp. 1515-1539, 2016.

41. R. Dehghani and M. Hosseininia, "Management strategy of small construction contractors during crisis and recession in building industry," QUID Investig. Cienc. y Tecnol., no. 28, pp. 69-77, 2017.

42. E. Głodziński, "How did the Project-based Companies Defend agains Impact of Economic Crisis? The Case,” J. Adv. Manag. Sci. Vol, vol. 5, no. 1, 2017.

43. Y. Shuai-ping, "Environmental Pollution in Construction Sites and Corresponding Green Construction Measures," Nat. Environ. Pollut. Technol., vol. 17, no. 4, pp. 1287-1292, 2018.

44. S. Kivrak, A. Ross, and G. Arslan, "Effects of cultural differences in construction projects: An investigation among UK construction professionals," in International conference on multi-national construction projects, 2008, pp. 1-11.

45. S. Mitkus and T. Mitkus, "Causes of conflicts in a construction industry: A communicational approach,” Procedia-Social Behav. Sci. vol. 110, pp. 777-786, 2014.

46. P. Hwang and J. D. Lichtenthal, “Anatomy of organizational crises,” J Contingencies Cris. Manag., vol. 8, no. 3, pp. 129-140, 2000.

47. S. Iqbal, R. M. Choudhry, K. Holschemacher, A. Ali, and J. Tamošaitienè, "Risk management in construction projects," Technol. Econ. Dev. Econ., vol. 21, no. 1, pp. 65-78, 2015.

48. K. Jayasudha and B. Vidivelli, "Analysis of major risks in construction projects,” ARPN J. Eng. Appl. Sci., vol. 11, no. 11, pp. 6943-6950, 2016.

49. J.-S. Chou and D. Pramudawardhani, "Cross-country comparisons of key drivers, critical success factors and risk allocation for public-private partnership projects,” Int. J. Proj. Manag., vol. 33, no. 5, pp. 1136-1150, 2015.

Blue Eyes Intelligence Engineering

\& Sciences Publication

(C) Copyright: All Rights Reserved

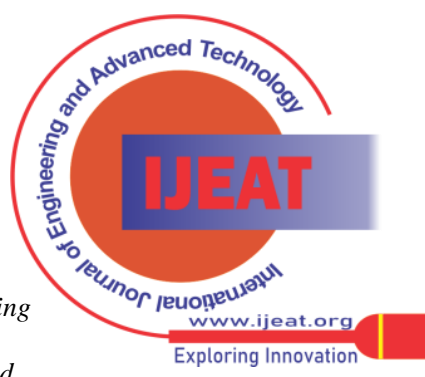


50. A. Enshassi, S. Mohamed, Z. A. Mustafa, and P. E. Mayer, "Factors affecting labour productivity in building projects in the Gaza Strip," J. Civ. Eng. Manag., vol. 13, no. 4, pp. 245-254, 2007.

51. S. Toor and S. O. Ogunlana, "Problems causing delays in major construction projects in Thailand," Constr. Manag. Econ., vol. 26, no. 4, pp. 395-408, 2008.

52. S. Zolfagharian, M. Nourbakhsh, J. Irizarry, A. Ressang, and M. Gheisari, "Environmental impacts assessment on construction sites," in Construction Research Congress 2012: Construction Challenges in a Flat World, 2012, pp. 1750-1759.

53. G. Zhang, "Construction project working site of environmental pollution and countermeasures," 2015.

54. J. M. Hussin, I. A. Rahman, and A. H. Memon, "The way forward in sustainable construction: issues and challenges," Int. J. Adv. Appl. Sci., vol. 2, no. 1, pp. 15-24, 2013.

55. S. Mishra and B. Mishra, "A study on risk factors involved in the construction projects,” Int. J. Innov. Res. Sci. Eng. Technol., vol. 5, no. 2, pp. 1190-1196, 2016.

56. D. D. Chaturvedi and M. Sharma, "economic recession and indian real estate-hopes and implications," readings b., p. 79, 2012.

57. N. Narendran, "The Residential Real-Estate Industry in India: Investigating Evidence for an Asset Bubble," 2013.

58. B. Ajinkya, M. Sujaan, S. Harshet, and I. Geetha, "Effects of Demonetization on the Real Estate Sector,” Pacific Bus. Rev. Int., vol. 10, no. 7, pp. 85-94, 2018.

59. W. A. Hatem and S. M. H. Al-Tmeemy, "The impact of terrorism on construction industry in Iraq," Wasit J. Eng. Sci., vol. 3, no. 2, pp. 69-84, 2015.

60. N. K. Acharya, Y. Dai Lee, and J. K. Kim, "Critical construction conflicting factors identification using analytical hierarchy process," KSCE J. Civ. Eng., vol. 10, no. 3, pp. 165-174, 2006.

61. O. C. Narh, E. E. Owusu, K. Oduro-Apeatu, and T.-W. J. Narh, “An exploratory study of professional conflicts and disputes within the construction industry," Int. J. Manag. Stud. Res., vol. 3, no. 12, pp. 44-65, 2015

62. M. Buckley, "From Kerala to Dubai and back again: construction migrants and the global economic crisis," Geoforum, vol. 43, no. 2, pp. 250-259, 2012.

63. S. Spangenberg, "An injury risk model for large construction projects," Risk Manag., vol. 11, no. 2, pp. 111-134, 2009.

64. A. Suffian, "Some common maintenance problems and building defects: Our experiences," Procedia Eng., vol. 54, pp. 101-108, 2013.

65. M. Madic and M. Radovanović, "Ranking of some most commonly used nontraditional machining processes using ROV and CRITIC methods,” UPB Sci. Bull., Ser. D, vol. 77, no. 2, pp. 193-204, 2015.

66. E. K. Zavadskas, Z. Turskis, J. Antucheviciene, and A. Zakarevicius, "Optimization of weighted aggregated sum product assessment," Elektron. ir elektrotechnika, vol. 122, no. 6, pp. 3-6, 2012.

\section{AUTHORS PROFILE}

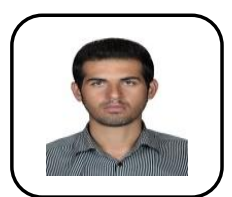

Seyed Ali Mousavi Dehmourdi, is a Research Scholar in the Department of Civil Engineering, University College of Engineering, Osmania University, Hyderabad, India. His main research area includes Construction Engineering, Management, and Construction Contractors' Assessment.



M. Gopal Naik, is a Professor in the Department of Civil Engineering, University College of Engineering, Osmania University, Hyderabad, India. His main research area includes Urban Watershed Management, Geospatial Techniques (Remote Sensing, GIS \& GPS), and Construction Engineering, Management.

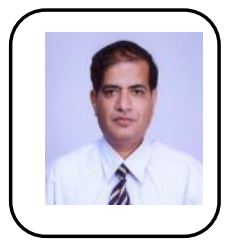

Ravande Kishore, is the Principal of MIT School of Engineering, Pune, Maharashtra, India. His main research area includes Recycled Aggregate Concrete, Concrete Technology Low-Cost Housing, Innovative materials for Construction, and Solid Waste Technology and management.

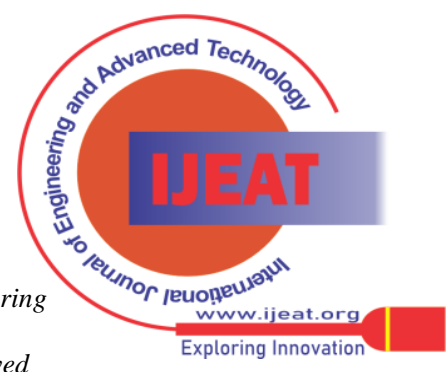

